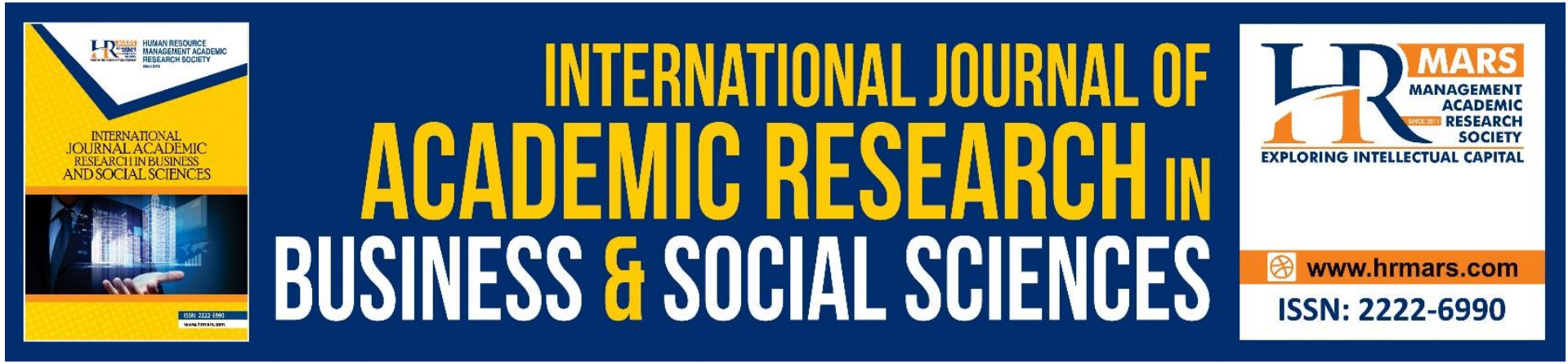

\title{
Factors Influencing of Islamic Banking by Customers: A Case Study in Northern Malaysia
}

Siti Sarah Januri, Muhammad Asyraf Muhamad Pozi, Muhammad Hakimie Nadzri and Muhammad Syafiq Zainuddin

To Link this Article: http://dx.doi.org/10.6007/IJARBSS/v11-i7/10530

DOI:10.6007/IJARBSS/v11-i7/10530

Received: 22 May 2021, Revised: 25 June 2021, Accepted: 14 June 2021

Published Online: 28 July 2021

In-Text Citation: (Januri et al., 2021)

To Cite this Article: Januri, S. S., Pozi, M. A. M., Nadzri, M. H., \& Zainuddin, M. S. (2021). Factors Influencing of Islamic Banking by Customers: A Case Study in Northern Malaysia. International Journal of Academic Research in Business and Social Sciences, 11(7), 720-735.

Copyright: @ 2021 The Author(s)

Published by Human Resource Management Academic Research Society (www.hrmars.com)

This article is published under the Creative Commons Attribution (CC BY 4.0) license. Anyone may reproduce, distribute, translate and create derivative works of this article (for both commercial and non-commercial purposes), subject to full attribution to the original publication and authors. The full terms of this license may be seen at: http://creativecommons.org/licences/by/4.0/legalcode

Vol. 11, No. 7, 2021, Pg. 720 - 735

Full Terms \& Conditions of access and use can be found at http://hrmars.com/index.php/pages/detail/publication-ethics 


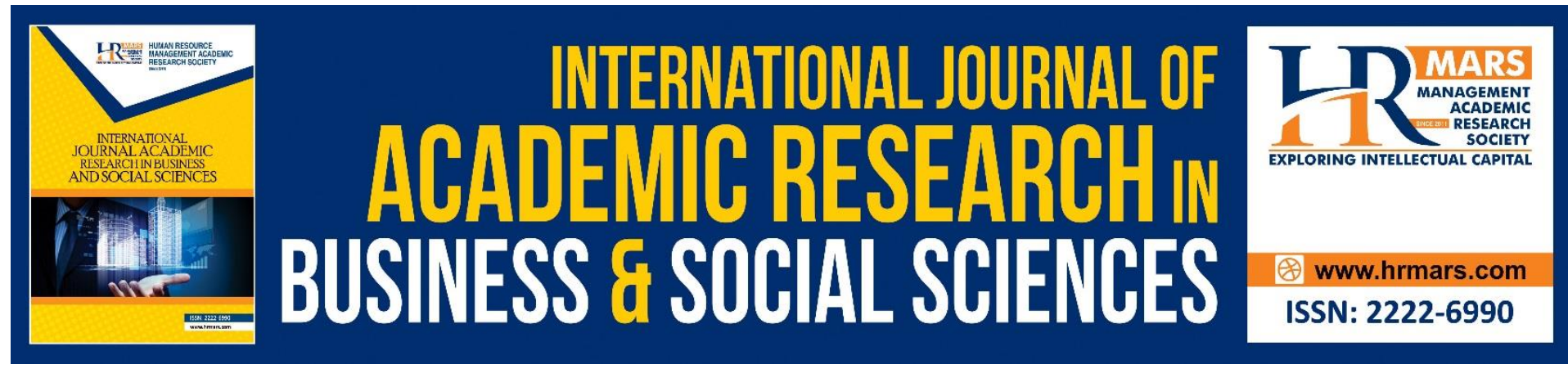

\title{
Factors Influencing of Islamic Banking by Customers: A Case Study in Northern Malaysia
}

\author{
Siti Sarah Januri, Muhammad Asyraf Muhamad Pozi, \\ Muhammad Hakimie Nadzri and Muhammad Syafiq Zainuddin \\ Faculty of Computer and Mathematical Sciences, Universiti Teknologi MARA, Negeri \\ Sembilan Branch, Seremban Campus, Seremban, 70300 Negeri Sembilan, MALAYSIA
}

\begin{abstract}
This research develops the understanding of the methodology and the application of Analytical Hierarchy Process (AHP) in the selection of the best criteria for Islamic banking. The AHP is a general problem-solving methodology that is useful for complex multi-criteria decision-making with variables that do not have the exact numerical consequences. The research study was undertaken involving bank customers in the Northern region of Malaysia. The objectives of the study are to identify the most important criteria for selecting Islamic banking by customers and to determine the major factors of selecting Islamic banking based on demographic variables (gender, religion). The AHP evaluates a hierarchy of criteria of the study including bank status, facilities provided, convenience, religion status, bank reputation, Sharia' issues, staff friendliness, and profitability. The best criterion which was chosen by all respondents was Sharia' issues while bank status was the least preferred by the customers. In addition, in analyzing the major factors of selecting Islamic banking between demographic variables, the most important criteria chosen by gender was Sharia' issues for males and bank reputation for females. Furthermore, the most important criterion chosen by Muslims was Sharia' issues and convenience factor for non-Muslims. These findings benefit the banks and customers: the bank is able to identify their potential customers and specific customer segments, while creating awareness for customers to choose Islamic banking. Future research would include other variables in the survey instrument such as safety and security.
\end{abstract}

Keywords: Islamic Banking, Analytical Hierarchy Process, Northern Malaysia

\section{Introduction}

Throughout the 1970's, Islamic banking grew rapidly around the world and continues to show very positive growth to this day. The origin of Islamic finance dates back to the dawn of Islam 1,400 years ago and currently, Islamic banking is expanding not only in nations where a majority of the population are Muslims, but also in other countries where Muslims are a minority (Shahdila et al., 2017). A uniqueness of Islamic banking is the services, products, and operation that follow the Sharia'. The major difference between Islamic banking and conventional banking is its system of banking. Islamic banking is an ethical banking system which practices Islamic principles. All banking transactions prohibited by Islam are not allowed such as riba'. On the other hand, the system or institutions of conventional banks are 
based on fully manmade principles that are the rule made by humans, usually considered in opposition to concepts like divine law.

Islamic banking is the choice of customers for many reasons. Islam does not allow usury that is also called riba' and offers low risk and all transactions have less interest. This is why Islamic banking attracts Muslim and non-Muslim investors alike. Islamic banking uses the Al-Quran and hadith as guidance "You who believe! Do not devour riba multiplying it over and keep your duty to Allah that you may prosper" as in the Sura Al-Imran (3:130). The advantages of Islamic banking are the chance to be aware of and share responsibility towards poverty, donate to charity, and reduce economic disparity.

Islamic banking has emerged as one of the fastest growing industries and is highly able to compete with conventional banking. The swift changes have caused the changes in customers' need and also their potential to have greater quality of banking services. For Malaysia, there are many products and services for banking sectors that can be chosen by customers to meet their needs and wants due to the existence of dual banking systems. Islamic banking needs to consider their bank's reputations and also the performance based on transaction speed in the delivery system, product diversity and banking convenience to attract more customers in order to purchase their products and services. Thus, before executing any Islamic products or services, the criteria based on individual perception need to be identified so that the desired outcomes in the future can be realized.

Islamic banking has been a rapidly growing sector particularly in Malaysia and possibly in the world, and it acts as an alternative to conventional banking nowadays. It is very important for the management of Islamic banking to ensure that all the transactions and products of Islamic banking are in accordance to the principles of sharia' at all times and at all costs. According to (Abduh \& Omar, 2014) there were six criteria, namely, bank reputation, bank status, profitability, facilities provided, staff friendliness, and sharia' issues on banking products and activities to see how Islamic bank customers in Malaysia rank the criteria based on the level of importance. This is due to the fact that sharia' requirements are the backbone of Islamic banking. A study conducted by (Amin, 2008) on the selection criteria on Islamic home financing in Labuan, Malaysia showed that there were five best criteria influencing customer choice, which were Sharia' principles, lower monthly payment, transparency practice, interest-free practice and 100 per cent financing. The Islamic banks should not follow the way of the conventional banks and the Islamic banks need to increase compliance in accordance with the principles of Sharia'.

Amongst the customers residing in the Klang-Valley, the sharia'-compliant criterion was the highest option before a customer chooses an appropriate Islamic bank (Abduh \& Omar, 2014) but (Awan \& Bukhari, 2011) found the contradicting results showing sharia' as the least important factor while the major factors of selecting Islamic banking in Pakistan were product features and service quality. Another study by (Naser, Jamal \& Khatib, 1999) in Jordan showed that they were more focused on sharia' issues to select the Islamic banking because the bank operates with Islamic teachings so it maintains good reputation and provides confidence for the clients in conducting its operation and disclosing information. 
A study conducted in Turkey showed that the majority of respondents put religious belief as the most important factor in dealing with banks (Okumus \& Genc, 2013). Other studies showed that the respondents from seven public financial institutions in Malaysia also supported that the most important factor in choosing an Islamic bank is religious values (Idris et al., 2011), and one of the results from the study of efficiency of ASEAN bank from 20102013, as highlighted by a recent study by Wanke, Hassan, \& Gavião (2017), found that that the principles of Islam is an important criteria in selecting Islamic banks.

Profitability is when the customers of the bank don't want to lose or have financial gain. The study by (Subhani, Hasan, Rafiq, Nayaz \& Osman, 2012) said that high profit and low service charge were the main factors considered by the respondents in Pakistan in choosing Islamic banking. Facilities criterion provided by the Islamic bank was one of the factors that attract customers to choose Islamic banking. Based on the study by (Katircioglu, Tumer \& Kılınç, 2011) the number of ATMs (facilities provided) was the most important selection criterion for Islamic banking by customers from two cities (Burcharest and Constanta) in Romania. Next, in a study conducted by (Naser et al., 1999) showed customer satisfaction on facilities provided by the Islamic bank because of physical evidence in the promotional material.

Staff friendliness showed by Islamic bank staff can also attract customers to choose an Islamic bank. In a study conducted by (Haron, Ahmad \& Planisek, 1994) in looking at the differences in the criteria chosen by Muslims and non-Muslims, two different options emerged between them. The non-Muslims chose friendliness of bank personnel as the most important factor before choosing an Islamic bank, while the Muslims believed that religion was the main factor on why people maintain an account with an Islamic bank. Convenience is when the customers are able to proceed with something without difficulty. A study by (Marimuthu, Jing, Gie, Mun \& Ping, 2010) showed four main factors, namely cost-benefit, service delivery, convenience, and influence by friends in choosing Islamic banking. This proves that the choosing of Islamic bank is not necessarily based on religious reasons although this study is conducted on Muslims and non-Muslims. Furthermore, for a bank to succeed, it needs to understand and fulfil the customer's wishes. Hence, the Islamic bank awares of the factors that are desired by Muslim customers, if Muslims chose Islamic banks based on the factor of "fast and efficient service" (Haron et al., 1994).

Every bank has its own reputation. For example, a bank with a good reputation can form bankclient relationships through lending financial support in cases of financial distress. Therefore, the customer needs to choose the bank based on the bank's reputation. The top most criterion chosen by the customers for Islamic home financing in Pakistan, in guaranteeing loyalty to the bank was the reputation of the bank (Hamid \& Masood, 2011).The results are the same with the study conducted by (Ismail, Azmi \& Thurasamy, 2014) stating that the majority of customers are confident of the Islamic home financing banks because the Islamic banks have a good reputation in Malaysia. This is supported by the study by (Bassir, Zakaria, Hasan \& Alfan, 2014) conducted in the Klang Valley to study the major factors influencing Islamic home financing adoption - it showed the results that support the religiosity and reputation of banks were the highest factors. The bank has the responsibility to provide basic banking services to customers as stated in the legislation. The bank status will basically take into consideration the most preferable banking services chosen among the banks by the 
customers. So, the bank status is the factor that convinces customers to select Islamic banking.

The Analytical Hierarchy Process (AHP) is a method used by (Saaty, 1987) to solve general problems for complex multi criteria decisions with variables that do not have exact numerical consequences (Batagarawa, William, Potts \& Brown, 2015). With the presence of various attributes in the selection of Islamic banks (Abduh \& Omar, 2014), The AHP is used as a major tool analysis. Several factors that influence the comparing of criteria for selecting Islamic banks in many countries are included in the AHP matrix of pairwise comparison. It aims to identify the most important criteria selected, and Malaysian banks (Abduh \& Omar, 2014) to use the AHP to set up customer patronizing patterns, including Islamic banks. Furthermore, (Attaran \& Celik, 2013) also used AHP as a method of analysis in their studies because the researchers want to see consumer ranking and the weight of the categories belonging to major green building rating system. Hence, to support (Abduh \& Omar, 2014) and (Attaran \& Celik, 2013), a study by (Ghasempour \& Salami, 2016) was conducted to see the difference in the performance of Iranian banks based on the CAMELS rating system using the AHP to see which factors are most important. In Pakistan, a study by (Bukhari, Awen \& Ahmed, 2013) was conducted using the AHP to analyze the corporate governance indexes on five Islamic banks and twelve conventional banks which provide Islamic banking facilities around Pakistan.

In the AHP, the pairwise comparison matrix is used for comparisons between criteria. The pairwise comparison matrix is calculated by using the geometric mean. A study by (Yadav \& Jayswal, 2013) stated that the geometric mean was used for analysis of functional layout parameters. By using this method, the firm can increase their outcomes. Next, the geometric mean was also used by (Dong, Zhang, Hong \& Xu, 2010) to measure the consensus degree among judgement matrices for AHP. Hence to support (Yadav \& Jayswal, 2013) , the study by (Kim, Kang \& Kim, 2015) also applied the Geometric mean method to resolve data imbalance problems in business domains. Furthermore, the study by (Wedley, 1993) stated that the geometric mean can be used with incomplete comparisons matrix to predict the consistency ratio and the consistency index.

In this research, eight variables are identified. The variables are profitability, bank status, bank reputation, facilities provided, staff friendliness, convenience, Sharia' issues, and religion status. In addition, the importance of Islamic banking is in response to the needs of the Muslim community and that Islamic banking is suitable for all religions. The significance of the research study is important in determining the benefits of the study as it will give a huge impact to the customers and Islamic banks. For the bank customers, they will be able to figure out the best selection criteria by customers before selecting an Islamic bank. On the other hand, the Islamic banks will be able to find out the needs and wants of the customers. Thus, the research study will give an appropriate guide to the Islamic bankers in developing better policies in order to improve the quality of the banking system. The aim of this research is to investigate how individuals look and pick the criteria before using an Islamic bank's service. 


\section{Methodology}

The primary focus of the research is Islamic banking and the scope of the research includes customers in Alor Star, Kedah, Georgetown, Penang, and Ipoh, Perak. These three locations were chosen because of their status as capital cities which involve all economies in the Northern region of Malaysia. In this study, 40 respondents were chosen as sample. The result are not affected by the small sample size as the AHP method was used to analyze the data (Sambasivan \& Fei, 2008). The nonprobability sampling method has been conducted to get data from the respondents. It is a relatively simple method to obtain data in a shorter time. The AHP Scale was used to measure respondents' agreement with a variety of statements. There is five-point-comparison scale used to generate the quantitative measurement. The importance of criteria determined by the procedure and the factors influencing the criteria are decided by the AHP.

This research develops the understanding of the methodology and the application of the AHP for selecting the most important criteria by Islamic banking customers. The AHP evaluates a hierarchy of criteria including profitability, bank status, facilities provided, staff friendless, Sharia' issues, convenience, religion status and bank reputation. There are eight criteria that are used, such as profitability, bank status, facilities provided, staff friendless, Sharia' issues, convenience, religion status and bank reputation. The table below shows the definition for each criterion.

Table 1. Definition of criteria

\begin{tabular}{|l|l|}
\hline Criteria & Explanation \\
\hline Profitability & $\begin{array}{l}\text { The degree to which a business or activity yields profit or financial } \\
\text { gain. }\end{array}$ \\
\hline Bank Status & $\begin{array}{l}\text { The most bank that citizens choose for the services that are } \\
\text { offered. }\end{array}$ \\
\hline Various Facilities & Various facilities that customers can deal with the bank. \\
\hline Staff Friendliness & Staff friendliness based on the behavior of staff. \\
\hline Sharia' Issues & $\begin{array}{l}\text { Sharia' requirements being the backbone of Islamic banking and its } \\
\text { teaching to maintain good reputation of Islam. }\end{array}$ \\
\hline Religion Status & $\begin{array}{l}\text { Islamic bank provides Sharia' compliant products and the majority } \\
\text { of respondents put religion as the most important factor in dealing } \\
\text { with the bank. }\end{array}$ \\
\hline Convenience & $\begin{array}{l}\text { Convenience is when the customers are being able to proceed with } \\
\text { something without difficulty. }\end{array}$ \\
\hline Reputation & Belief and trust from respondents based on past performance \\
\hline
\end{tabular}

\section{The Analytical Hierarchy Process (AHP)}

The Analytical Hierarchy Process (AHP) is a decision tool for dealing with complex, unstructured, and multiple criteria decision making (MCDM). There are three major steps in the AHP. Firstly, there is the description of a complex problem such as a hierarchy. Second is the use of pairwise comparisons to estimate the importance of criteria on each level of hierarchy. Lastly is the integration of pairwise comparison to evaluate decision alternatives. The steps in AHP are as follows. 
Step 1: List of Goal and Criteria in Hierarchy Structure

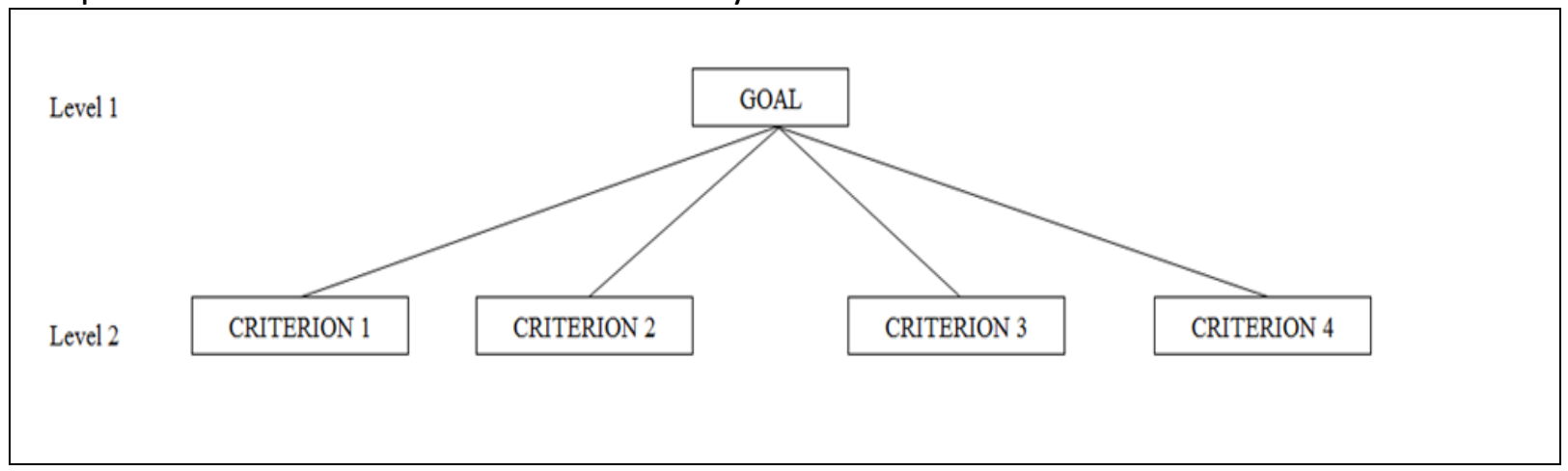

Figure 1. Structure of AHP

Step 2: Develop a Pairwise Comparison Matrix for criteria

- Develop a pairwise comparison matrix based on the relative importance between each pair of criteria. The matrix lists the criteria horizontally and vertically and has the numerical ratings comparing between the importance of criteria.

- The rating of the pairwise comparison is based on and referred to Table 2, which shows the intensity of importance with its definition labeled 1 to 9 (Byun, 2001). The range that indicates relative weight of alternative was changed from 1-9 to 1-5. Furthermore the rank of the priority of alternatives were also changed (Hossain, Adnan \& Hasin, 2014)

Table 2. The AHP Ratings

\begin{tabular}{|l|l|}
\hline Intensity of Importance & Definition \\
\hline 1 & Equally important \\
\hline 2 & Moderate importance of one over another \\
\hline 3 & Essential or of strong importance \\
\hline 4 & Very strong importance \\
\hline 5 & Extreme importance \\
\hline
\end{tabular}

Examples:

- If profitability is strongly more important than bank status, then bank status must be strongly less important than profitability. Profitability is graded at 3 and bank status is $1 / 3$.

Step 3: Priority vector according to the Geometry Mean

Multiply each element in every row and then to the power of $1 / \mathrm{n}$ and sum all the total row.

$$
\bar{x}=\sqrt[n]{\prod_{i=1}^{n} x}
$$

$$
\text { sum the total row }=\sum \sqrt[n]{\prod_{i=1}^{n} x}
$$

Step 4: Develop a Normalized Matrix

Normalize each total of the row by dividing the total row by the total sum of the rows. 
Step 5: Develop the Priority Vector

$$
\text { normalize }: \frac{\sqrt[n]{\prod_{i=1}^{n} x}}{\sum \sqrt[n]{\prod_{i=1}^{n} x}}
$$

Average each row of the normalized matrix. These row averages form the priority vector of criteria preferences with respect to the particular criterion. The values in this vector sum to 1 .

$$
\sum \frac{\sqrt[n]{\prod_{i=1}^{n} x}}{\sum \sqrt[n]{\prod_{i=1}^{n} x}}=1
$$

Step 6: Calculate a Consistency Ratio (CR)

- Determining the consistency Ratio

Step 6.1: For each row of the pairwise comparison matrix, determine a weighted sum by summing the multiples of the entries by the priority of its corresponding criteria. Weightage represents the results by the respondents based on the ranking between

criteria.

Step 6.2: For each row, divide its weighted sum by the priority of its corresponding (row) alternative.

Step 6.3: Determine the average, $\lambda_{\max }$, of the results of Step 6.2.

Step 6.4: Compute the consistency index, $\mathrm{Cl}$, of the $n$ alternatives by:

$$
C I=\left(\lambda_{\max }-n\right) /(n-1)
$$


Table 3 shows random and cut-off consistency indexes.

Table 3. Saaty cut-off consistency indexes (Wedley, 1993).

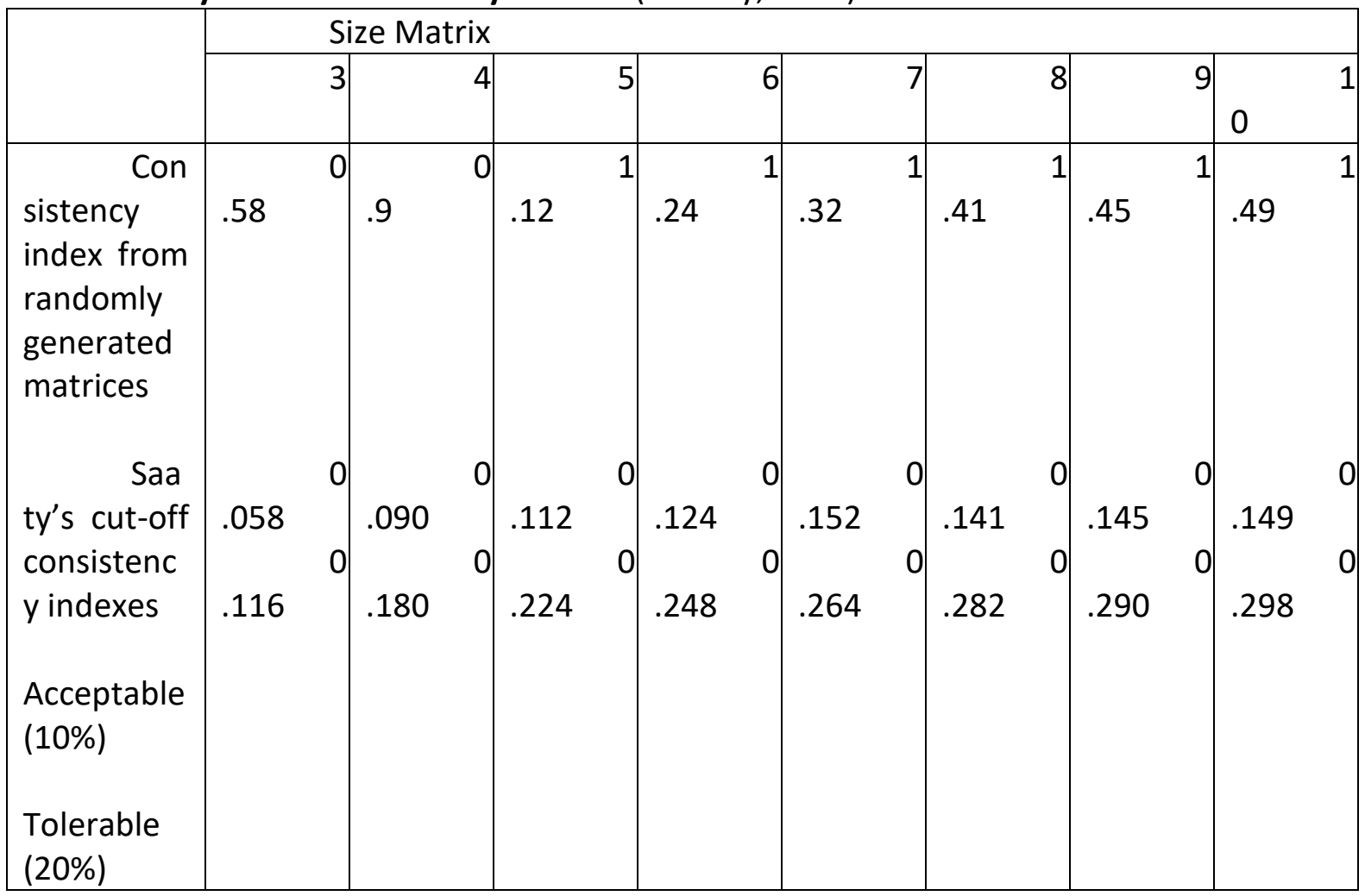

- It is tolerable if the ratio $<0.282$

Step 6.5: Determine the random index, RI, from the following Table 3

Step 6.6: Compute the consistency ratio (CR)

$$
C R=\frac{C I}{R C I}
$$

Table 4. $\mathrm{RCl}$ values (Yadav \& Jayswal, 2013)

\begin{tabular}{|l|l|l|l|l|l|l|l|l|l|}
\hline $\mathrm{N}$ & 1 & 2 & 3 & 4 & 5 & 6 & 7 & 8 & 9 \\
\hline $\mathrm{RI}$ & 0.00 & 0.00 & 0.58 & 0.90 & 1.12 & 1.24 & 1.32 & 1.41 & 1.45 \\
\hline
\end{tabular}

$\mathrm{N}=$ no. of items compared

The consistency of the subjective input in the pairwise comparison matrix can be measured by calculating a consistency ratio.

- $\mathrm{CR}=\mathrm{CR} / \mathrm{RCl} \quad(C R \leq 0.1)$ is good.

- For $C R>0.1$, revise the judgments to locate the cause of the inconsistency and correct it

\section{Results and Discussion}

This section discusses the characteristics of the respondents. The result shown is the percentage of respondent characteristics involved in this study. 


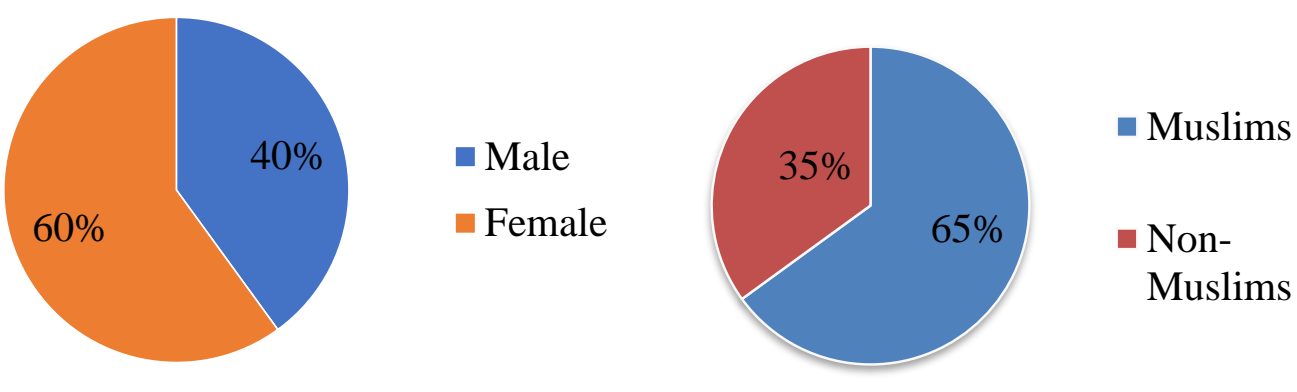

Figure 2. Percentage of respondents by Gender and Religion

Figure 2 shows the percentage of all respondents by gender and religion. From the findings, the female respondents have the higher percentage being involved in this study by $60 \%$, while the male respondents have the lower percentage of $40 \%$. For the percentage of all respondents by religion, the findings indicate that the Muslim respondents have the higher percentage being involved in this study by $65 \%$ and the non-Muslim respondents have the lower percentage of $35 \%$.

The data was analyzed using the AHP procedure to show the significant criteria. The total for each priority vector for every respondent should be equal to 1 and the result should be consistent for pair wise comparison matrix less than 0.1 , as a value of more than 0.1 is not recommended by many of the experts. Therefore, the matrix must be adjusted and calculated: a consistency ratio (CR) can be obtained by dividing consistency index (CI) by random index (RI). There was a calculation of CR for the first respondent. The table below shows the pairwise comparison matrix, normalized matrix and priority vector for respondent 1.

Table 5. Names of Criteria

\begin{tabular}{|l|l|}
\hline Criteria & Name of Criteria \\
\hline C1 & Profitability \\
\hline C2 & Bank status \\
\hline C3 & Various facilities \\
\hline C4 & Staff friendliness \\
\hline C5 & Sharia' issues \\
\hline C6 & Religion status \\
\hline C7 & Convenience \\
\hline C8 & Reputation \\
\hline
\end{tabular}


Table 6. Pairwise Comparison Matrix

\begin{tabular}{|l|l|l|l|l|l|l|l|l|}
\hline & C1 & C2 & C3 & C4 & C5 & C6 & C7 & C8 \\
\hline C1 & 1 & 3 & 0.25 & 0.25 & 0.3333 & 1 & 1 & 1 \\
\hline C2 & 0 & 1 & 1 & 0.3333 & 2 & 0.3333 & 1 & 1 \\
\hline C3 & 4 & 1 & 1 & 0.3333 & 2 & 1 & 0.3333 & 0.3333 \\
\hline C4 & 4 & 3 & 3 & 1 & 3 & 0.3333 & 3 & 0.3333 \\
\hline C5 & 3 & 0.5 & 0.5 & 0.3333 & 1 & 0.25 & 1 & 0.3333 \\
\hline C6 & 1 & 3 & 1 & 3 & 4 & 1 & 3 & 1 \\
\hline C7 & 1 & 1 & 3 & 0.3333 & 1 & 0.3333 & 1 & 1 \\
\hline C8 & 1 & 1 & 3 & 3 & 3 & 1 & 1 & 1 \\
\hline
\end{tabular}

The priority vector indicates relative weights among the criteria that the research wants to compare. To calculate priority vector, this study used the geometric mean method to compute it.

i. First multiply all element in row and power by $1 / n$ where $n$ is number of criteria.

Then, calculate for each criterion :

$$
\text { criteria } 1:(1 \times 3 \times 0.25 \times 0.25 \times 0.3333 \times 1 \times 1 \times 1)^{\frac{1}{8}}=0.707106781
$$

ii. Then, sum all the total row and divide each total row by sum of total row to obtain the priority vector. After this, calculate for each criterion:

$=0.707106781+0.722284473+0.858945834$

Sum of total row

$+1.56508458+0.616374758+1.795469241+0.871685543$

$+1.509803648=8.64675486$

Priority vector for Criteria $1: \frac{0.707106781}{8.64675486}=0.081777128$

Table 7. Normalized Matrix and Priority Vector

\begin{tabular}{|l|l|l|}
\hline Criteria & Normalized Matrix & Priority Vector \\
\hline 1 & 0.707106781 & 0.081777128 \\
\hline 2 & 0.722284473 & 0.083532433 \\
\hline 3 & 0.858945834 & 0.099337364 \\
\hline 4 & 1.56508458 & 0.181002539 \\
\hline 5 & 0.616374758 & 0.07128394 \\
\hline 6 & 1.795469241 & 0.207646599 \\
\hline 7 & 0.871685543 & 0.100810715 \\
\hline 8 & 1.509803648 & 0.174609281 \\
\hline Total & 8.64675486 & 1 \\
\hline & & \\
\hline
\end{tabular}

iii. Calculate the consistency index(Cl)

$$
\begin{aligned}
C I & =\left(\lambda_{\max }-n\right) /(n-1) \\
= & \frac{(8.64675486-8)}{(8-1)} \\
& =0.092394
\end{aligned}
$$


iv. Calculate the consistency ratio(CR)

$$
C R=\frac{C I}{R C I}
$$

*random consistency index $(\mathrm{RCl})$ for 8 criteria is 1.41

$$
\begin{aligned}
C R & =\frac{0.092394}{1.41} \\
& =0.065527
\end{aligned}
$$

Table 8. Table of Consistency

\begin{tabular}{|l|l|}
\hline Consistency Index & 0.092394 \\
\hline Random Consistency Index & 1.41 \\
\hline Consistency Ratio & 0.065527 \\
\hline
\end{tabular}

This step should be computed for 40 respondents - after that, all CR can be calculated by total of all CR for each respondent divided by the total of respondents. Table 9 shows the consistency ratio for each respondent.

Table 9. Consistency ratio for respondents (partial of respondents)

\begin{tabular}{|l|l|l|l|l|l|l|l|l|}
\hline Respondent & R1 & R2 & R3 & R4 & R5 & R6 & R7 & R8 \\
\hline CR & 0.1778 & 0.1641 & 0.1771 & 0.1727 & 0.1523 & 0.1098 & 0.2332 & 0.1624 \\
\hline
\end{tabular}

\begin{tabular}{|l|l|l|l|l|l|l|l|l|}
\hline Respondent & R8 & R10 & R11 & R12 & R13 & R14 & R15 & R16 \\
\hline CR & 0.2791 & 0.3153 & 0.3484 & 0.0377 & 0.0628 & 0.0138 & 0.0711 & 0.0863 \\
\hline
\end{tabular}

\begin{tabular}{|l|l|l|l|l|l|l|l|l|}
\hline Respondent & R17 & R18 & R19 & R20 & R21 & R22 & R23 & R24 \\
\hline CR & 0.2541 & 0.0883 & 0.128 & 0.1387 & 0.158 & 0.2786 & 0.1185 & 0.0957 \\
\hline
\end{tabular}

\begin{tabular}{|l|l|l|l|l|l|l|l|l|}
\hline Respondent & R25 & R26 & R27 & R28 & R29 & R30 & R31 & R32 \\
\hline CR & 0.0667 & 0.1047 & 0.1091 & 0.1047 & 0.0655 & 0.2679 & 0.1792 & 0.2378 \\
\hline
\end{tabular}

\begin{tabular}{|l|l|l|l|l|l|l|l|l|}
\hline Respondent & R33 & R34 & R35 & R36 & R37 & R38 & R39 & R40 \\
\hline CR & 0.1674 & 0.27 & 0.3543 & 0.0787 & 0.0554 & 0.2438 & 0.1245 & 0.2796 \\
\hline
\end{tabular}

Average of $\mathrm{CR}=6.5331 / 40=0.1633$

If the value of consistency ratio is less than $10 \%$, the consistency is acceptable but if the consistency ratio is greater than $10 \%$, it needs to be revised using the subjective judgment. Besides that, this indicates the data as being inaccurate. In this study, the consistency ratio came from the average of consistency ratio for every respondent. There are eight criteria in this study: refer to table above which shows the size matrix is 8 and tolerable for Saaty's cutoff was 0.282 . The consistency ratio for this study is 0.1633 that is below 0.282 of Saaty's cutoff consistency indexes. Thus, the result for this consistency ratio is tolerable. 


\section{Weightage of Criteria}

This section discusses the weightage values for each alternative that can be compared to create a rank order of their performance related to the all the criteria, as provided by all the respondents (Saaty 1987). The results show the ranking of criteria chosen by the respondents.

Table 10. Weightage of Criteria

\begin{tabular}{|l|l|l|}
\hline Criteria & Weightage & Rank Of Criteria \\
\hline Bank Status & 0.0779 & 8 \\
\hline Profitability & 0.1323 & 4 \\
\hline Facilities Provided & 0.1055 & 7 \\
\hline Staff Friendliness & 0.1155 & 6 \\
\hline Sharia' Issues & 0.1602 & 1 \\
\hline Convenience & 0.122 & 5 \\
\hline Religion Status & 0.1325 & 3 \\
\hline Bank Reputation & 0.1541 & 2 \\
\hline
\end{tabular}

Table 10 shows the weightage and rank of all respondents for all criteria. From Table 4.1, the rank of criteria chosen by the respondents is sharia' issues followed by bank reputation, religion status, profitability, convenience, staff friendliness, facilities provided and bank status. From the findings, $16 \%$ of the respondents chose sharia' issues as the most preferable criteria with the weightage of 0.1602 . Bank status is the least preferred criteria, having been chosen by $7.8 \%$ of the respondents with the weightage of 0.0779 .

\section{Weightage of Criteria by Demography}

This section will discuss the weightage of criteria based on the demographic data of the respondents, such as gender, religion, and occupation. The results show the rank of each criterion, from most important to the least important, as chosen by the respondents.

Table 11. Weightage of criteria by gender: male and female respondents

\begin{tabular}{|l|l|l|l|l|}
\hline Criteria & $\begin{array}{l}\text { Weightage for } \\
\text { Males }\end{array}$ & $\begin{array}{l}\text { Rank of } \\
\text { Criteria By } \\
\text { Males }\end{array}$ & $\begin{array}{l}\text { Weightage for } \\
\text { Females }\end{array}$ & $\begin{array}{l}\text { Rank } \\
\text { Criteria by } \\
\text { Females }\end{array}$ \\
\hline Bank Status & 0.0871 & 8 & 0.0717 & 8 \\
\hline Profitability & 0.1413 & 3 & 0.1262 & 5 \\
\hline Facilities Provided & 0.1025 & 6 & 0.1075 & 7 \\
\hline Staff Friendliness & 0.0977 & 7 & 0.1274 & 3 \\
\hline Sharia' Issues & 0.1675 & 1 & 0.1554 & 2 \\
\hline Convenience & 0.1196 & 5 & 0.1236 & 6 \\
\hline Religion Status & 0.1406 & 4 & 0.1270 & 4 \\
\hline Bank Reputation & 0.1437 & 2 & 0.1611 & 1 \\
\hline
\end{tabular}

Table 11 indicates the weightage of criteria chosen, according to the respondents' gender. The highest ranked criterion by male respondents is sharia' issues followed by bank reputation, profitability, religion status, convenience, facilities provided, staff friendliness, and bank status. This is different for the female respondents- the highest ranked criterion is bank reputation, followed by sharia' issues, staff friendliness, religion status, profitability, convenience, facilities provided, and bank status. 
From the findings, out of 40 respondents, 16 were male and 24 were female. The results show that the ranking of criteria for male and female is different. For the male respondents, 0.1675 (16.7\%) of males have chosen sharia' issues as the most preferable criterion but for the female respondent, the sharia' issues is only the second preferred criterion with $0.1554(15.5 \%)$ of the female respondents having chosen it. Bank reputation is the most preferred criterion for the female respondents with 0.1611 (16.1\%) of females having chosen it, but for the male respondents, bank reputation has become the second preference, chosen by $0.1437(14.4 \%)$ of them.

Table 12. Weightage of criteria by religion: Muslims and Non-Muslims

\begin{tabular}{|l|l|l|l|l|}
\hline Criteria & $\begin{array}{l}\text { Weightage for } \\
\text { Muslims }\end{array}$ & $\begin{array}{l}\text { Rank of } \\
\text { Criteria by } \\
\text { Muslims }\end{array}$ & $\begin{array}{l}\text { Weightage for Non- } \\
\text { Muslims }\end{array}$ & $\begin{array}{l}\text { Rank } \\
\text { Criteria by } \\
\text { Non-Muslims }\end{array}$ \\
\hline Bank Status & 0.0755 & 8 & 0.0823 & 6 \\
\hline Profitability & 0.1213 & 4 & 0.1525 & 4 \\
\hline Facilities Provided & 0.0933 & 6 & 0.1282 & 5 \\
\hline Staff Friendliness & 0.0934 & 5 & 0.1567 & 3 \\
\hline Sharia' Issues & 0.2158 & 1 & 0.0571 & 8 \\
\hline Convenience & 0.0891 & 7 & 0.1831 & 1 \\
\hline Religion Status & 0.1655 & 2 & 0.0712 & 7 \\
\hline Bank Reputation & 0.1462 & 3 & 0.1689 & 2 \\
\hline
\end{tabular}

Table 12 shows the weightage and the percentage of Muslims and non-Muslims respondents by criteria. The highest ranked criterion for Muslim respondents is sharia' issues followed by religion status, bank reputation, profitability, staff friendliness, facilities provided, convenience, and bank status and this differs from the non-Muslim respondents, where the criteria convenience, bank reputation, staff friendliness, profitability, facilities provided, bank status religion status and sharia' issues were ranked from highest to lowest.

From the findings, out of 40 respondents, 26 were Muslims and 14 were non-Muslims. The results show that the ranking of criteria for the Muslims and the non-Muslims is different. For the Muslim respondents, 0.2158 (21.6\%) chose the sharia' issues as the most preferable criterion but for the non-Muslims, sharia' issues is the preference with the smallest percentage which is 0.0571 (5.7\%). Convenience has become the most preferable criterion for the non-Muslim respondents with 0.1831 (18.3\%), but for the Muslim respondents, convenience is the second least preferred criterion, having been chosen by $0.0891(8.9 \%)$ of them.

\section{Conclusions and Recommendation}

In conclusion, the Analytical Hierarchy Process (AHP) is used to solve one of our daily life problems, which is selecting decision. By applying the Analytical Hierarchy Process (AHP) in the selection of Islamic banking criteria in Northern Malaysia, the results show that the best criterion chosen by all the respondents is Sharia' issues since the percentage of the criterion is the highest with the value of $16 \%$.

Besides that, the most important criteria chosen by gender is Sharia' issues for the males and bank reputation for the females with the percentage values of $16.7 \%$ and $16.1 \%$ respectively. 
Next, the most important criteria chosen by religion is Sharia' issues for Muslims and Convenience for non-Muslims with the highest percentages standing at $21.6 \%$ and $18.3 \%$, respectively.

The thoughts shared could be considered as avenues for future studies, possibly with the addition of other criteria such as economic reputation and product price factor. The future study should expand the study area to get more valuable research data.

\section{References}

Abduh, M., \& Omar, M. A. (2012). Islamic - Bank Selection Criteria In Malaysia : An AHP Approach. Business Intelligence Journal, 5(2), 217-281.

Amin, H. (2008). Choice criteria for Islamic home financing: Empirical investigation among Malaysian bank customers. International Journal of Housing Markets and Analysis, 1, 256-274.

Attaran, S., \& Celik, B. G. (2013). Analytic Hierarchy Process: An Application in Green Building Market Research. International Review of Management and Marketing,3(3), 122-133.

Awan, H. M., \& Bukhari, K. S. (2011). Customer's criteria for selecting an Islamic bank: evidence from Pakistan. Journal of Islamic Marketing, 2(1), 14-27.

Bassir, N. F., Zakaria, Z., Hasan, H. A., \& Alfan, E. (2014). Factors influencing the adoption of Islamic home financing in Malaysia. Transformations in Business and Economics, 13(1), 155-174.

Batagarawa, R., Williams, J., Potts, J., \& Brown, J. (2015). Use of Analytic Hierarchy Process (AHP) as an Instrument To Develop a Solid Waste Management Assessment Tool. Global Journal of Advanced Engineering Technologies, 4(2), 70-75.

Bukhari, K. S., Awan, H. M., \& Ahmed, F. (2013). An evaluation of corporate governance practices of Islamic banks versus Islamic bank windows of conventional banks: A case of Pakistan. Management Research Review, 36(4), 400-416.

Byun, D. (2001). The AHP approach for selecting an automobile purchase model. Information \& Management, 38 (5), 289-297.

Dong, Y., Zhang, G., Hong, W,. \& Xu, Y. (2010). Consensus models for AHP group decision making under row geometric mean prioritization method. Decision Support Systems, 49(3), 281-289.

Ghasempour, S., \& Salami, M. (2016). Ranking Iranian Private Banks Based on the CAMELS Model Using the AHP Hybrid Approach and TOPSIS. International Journal of Academic Research in Accounting, Finance and Management Sciences, 6(4): 52-62.

Hamid, A., \& Masood, O. (2011). Selection criteria for Islamic home financing : A case study of Pakistan. Qualitative Research in Financial Markets, 3(2), 117-130.

Haron, S., Ahmad, N., \& Planisek, S. L. (1994). Bank patronage factors of Muslimand nonMuslim customers. International Journal of Bank Marketing, 12 (1), 32-40.

Hossain, F., Adnan, Z. H., \& Hasin, M. A. A. (2014). Improvement in Weighting Assignment Process in Analytic Hierarchy Process by Introducing Suggestion Matrix and Likert Scale. International Journal of Supply Chain Management, 3(4), 91-95.

Idris, A. R., Naziman, K. N. M., Januri, S. S., Asari, F. F. A. H., Muhammad, N., Sabri, S. M., \& Jusoff, K. (2011). Religious Value as the Main Influencing Factor to Customers Patronizing Islamic Bank. World Applied Sciences Journal (Special Issue on Bolstering Economic Sustainability), 12, 8-13.

Ismail, S., Azmi, F., \& Thurasamy, R. (2014). Selection criteria for Islamic home financing in 
Malaysia. International Journal of Business and Society, 15(1), 97-110.

Katircioglu, S. T., Tumer, M., \& Kılınç, C. (2011). Bank selection criteria in the banking industry : An empirical investigation from customers in Romanian cities. African Journal of Business Management, 5(14): 5551-5558

Kim, M., Kang, D., \& Kim, H. B. (2015). Geometric mean based boosting algorithm with oversampling to resolve data imbalance problem for bankruptcy prediction. Expert Systems With Applications, 42, 1074-1082.

Marimuthu, M., Jing, C. W., Gie, L. P., Mun, L. P., \& Ping, T. Y. (2010). Islamic Banking: Selection Criteria and Implications. Global Journal of Human Social Science, 10(4), 52-62.

Naser, K., Jamal, A., \& Khatib, K. Al. (1999). Islamic banking: a study of customer satisfaction and preferences in Jordan. International Journal of Bank Marketing, 17(3), 135-151.

Okumus, H. S., \& Genc, E. G. (2013). Interest Free Banking In Turkey : A Study of Customer Satisfaction And Bank Selection. European Scientific Journal, 9(16), 1857 - 7881.

Saaty, R. W. (1987). The analytic hierarchy process-what and how it is used. Mathematical Modelling, 9(3), 161-176.

Sambasivan, M., \& Fei, N. Y. (2008). Evaluation of critical success factors of implementation of ISO 14001 using analytic hierarchy process ( AHP ): A case study from Malaysia. Journal of Cleaner Production, 16(13), 1424-1433.

Shahdila, W. S. S., Shahzlinda, W. S. S., Puad, N. M., Rafdi, N. J., Sanusi, S. W. S. A., \& Hassin, W. S. W. (2017). The Historical Development of Islamic Banking. Proceeding of the 4th International Conference on Management and Muamalah (ICOMM 2017), 503-508.

Subhani, M. I., Hasan, S. A., Rafiq, M. F., Nayaz, M., \& Osman, A. (2012). Consumer Criteria for the Selection of an Islamic Bank: Evidence from Pakistan. International Research Journal of Finance and Economics (IRJFE), 94.

Wanke, P., Hassan, M. K., \& Gavião, L. O. (2017). Islamic banking and performance in the Asean banking industry: A TOPSIS approach with probabilistic weights. International Journal of Business and Society, 18 (1), 129-150.

Wedley, W. (1993). Consistency prediction for incomplete AHP matrices. Mathematical and Computer Modelling, 17(4-5), 151-161.

Yadav, A., \& Jayswal, S. (2013). Using Geometric Mean Method of Analytical Hierarchy Process for Decision Making in Functional Layout. International Journal of Engineering Research \& Technology, 2(10), 775-779. 